\title{
ANALISIS MOTIVASI PEMANFAATAN PEKARANGAN UNTUK PERTANIAN PERKOTAAN DI KABUPATEN BUNGO
}

\author{
MOTIVATION ANALYSIS OF YARD UTILIZATION FOR \\ URBAN AGRICULTURE IN BUNGO DISTRICT
}

\author{
Supriyati \\ Progam Studi Manajemen, Fakultas Ekonomi, Universitas Muara Bungo \\ J1. Diponegoro No 27 Kelurahan Cadika, Kecamatan Rimbo Tengah Kabupeten Bungo, \\ Jambi 37211, Indonesia \\ Supriyaty76@Gmail.com
}

\begin{abstract}
ABSTRAK
Pertanian perkotaan terus berkembang dalam kaitannya dengan masalah lingkungan, ekonomi, kesehatan dan sosial, termasuk di Kota Muara Bungo. Agar pemanfaatan pekarangan ini dapat berkelanjutan dan berkesinambungan, pemanfaatan pekarangan haruslah menyesuaikan motivasi masyarakat itu sendiri. Tujuan penelitian ini adalah untuk mengetahui tingkat motivasi lingkungan, ekonomi, kesehatan dan sosial/kemasyarakatan dalam memanfaatkan pekarangan untuk usaha tani. Penelitian ini menggunakan metode penelitian deskriptif dengan pendekatan kualitatif dan teknik survei menggunakan kuesioner kepada 79 responden. Motivasi diukur menggunakan skala Likert dari item pernyataan.

Hasil penelitian menunjukkan bahwa motivasi masyarakat secara berurutan dari yang tinggi ke rendah yaitu motivasi kesehatan, motivasi lingkungan, dan motivasi ekonomi dan motivasi sosial/kemasyarakatan. Perencanaan dan kebijakan pertanian di perkotaan khususnya di pekarangan harus memberi perhatian khusus pada kegiatan pertanian perkotaan ini karena memberi manfaat dalam Kesehatan dan sosial berupa pemanfaatan waktu luang dan gotong-royong antar warga,dengan mengimplementasikan konsep pembangunan berkelanjutan yang disesuaikan dengan motivasi masyarakat itu sendiri.
\end{abstract}

Kata kunci: Motivasi; Pekarangan; Pertanian perkotaan

\section{ABSTRACK}

Urban agriculture continues to develop in relation to environmental, economic, health and social issues, including in Muara Bungo City. In order for the use of this yard to be sustainable and sustainable, the use of the yard must adjust the motivation of the community itself. The purpose of this study was to determine the level of environmental, economic, health and social/community motivation in utilizing the yard for farming. This study uses descriptive research methods with a qualitative approach and survey techniques using questionnaires to 79 respondents. Motivation is measured using a Likert scale of statement items.

The results showed that people's motivations sequentially from high to low were health motivation, environmental motivation, and economic motivation and social/social motivation. Agricultural planning and policies in urban areas, especially in the yard, must pay special attention to urban agricultural activities because they provide health and social benefits in the form of the use of free time and mutual cooperation between residents, by implementing the concept of sustainable development that is adapted to the motivation of the community it self. 
Key words : Motivation; yard; Urban farming

\section{Pendahuluan}

Dengan semakin berkurangnya wilayah pertanian secara tidak langsung menyebabkan ketersediaan pangan di kawasan perkotaan akan terus menurun, yang mengakibatkan kawasan perkotaan terancam mengalami persoalan ketahanan pangan.

Studi tentang pertanian perkotaan terus berkembang dalam kaitannya dengan masalah lingkungan, ekonomi, kesehatan dan sosial kemasyarakatan (Mcclintock, 2010; Guitart, Pickering dan Byrne, 2012; Horst dkk, 2017). Pertanian perkotaan tidak hanya dalam dimensi kegiatan pertanian tanaman hortikultura saja, namun juga pada kegiatan peternakan.

Berusaha tani di tengah kota mempunyai tantangan tersendiri, mulai dari sumber daya (lahan, media tanam, air), iklim, serta lingkungan sosial dan budayanya. Pada masyarakat perkotaan yang heterogen, sikap terhadap lingkungan akan berbeda pada setiap individu dan rumah tangga. Sehingga hal ini menimbulkan perbedaan motivasi masyarakat perkotaan untuk memanfaatkan pekarangan tersebut.

Pemanfaatan pekarangan ini dapat berkelanjutan dan berkesinambungan, haruslah menyesuaikan dengan motivasi masyarakat itu sendiri. Motivasi lingkungan menjadi motivasi utama masyarakat di beberapa kota besar, melaksanakan pertanian (Ciftcioglu, 2017; Trendov, 2018) dan (Gusfarina dan Irham, 2019) Pertanian perkotaan, menambah ruang terbuka hijau, dan memperbaiki kualitas lingkungan,seperti memberikan manfaat estetik dan psikologis sebagai sarana rekreasi.

Motivasi ekonomi yang mendasari masyarakat perkotaan melakukan usahatani diantaranya sebagai sumber makanan keluarga, mengurangi pengeluaran, mendukung ketahanan pangan keluarga menambah pendapatan rumah tangga (Simatele dan Binns, 2008;
Battersby dan Marshak, 2013), serta mengurangi biaya transportasi (Mcclintock, 2010), (Fikriman. Dkk, 2020) juga menyatakan bahwa Secara bersamasama atau serempak pendapatan, pendidikan ibu rumah tangga, jumlah anggota keluarga dan bantuan sosial terhadap pangan berpengaruh terhadap pengeluaran pangan rumah tangga miskin, maka dengan itu dengan memanfaatkan pekarangan bisa mengurangi pengeluaran rumah tangga.

Manfaat Kesehatan juga menjadi motivasi yang mempengaruhi untuk ikut berpartisipasi dalam pemanfaatan pekarangan di perkotaan (Egli dkk, 2016).

Masyarakat kota mengakui makanan yang mereka produksi sendiri lebih segar, bergizi dan sehat (Gauder dkk, 2018). Namun manfaat kesehatan yang lebih luas adalah bagaimana berusahatani di pekarangan membantu mereka secara psikologis men anamkan kedisiplinan dan kesabaran dan juga menjaga kesehatan fisik (Dunn, 2010)

Manfaat lain dari pertanian di perkotaan adalah tempat membangun komunitas dan sarana pendidikan (Turner, 2011). Motivasi pribadi utama individu mengambil bagian dalam pertanian perkotaan adalah adanya kesempatan bersosialisasi, dan juga melestarikan budaya menanam (Hovorka, 2008; Battersby dan Marshak, 2013).

Dalam pernyataan (Fikriman, 2017) bahwa Penyebab semakin memburuknya kinerja pertanian di negara berkembang adalah karena banyak negara berkembang yang memiliki daerah pertanian yang cukup luas namun tidak bisa memanfaatkan kelebihan luas lahan pertanian yang mereka miliki, maka dengan adanya pemanfaatan lahan pekarangan kita dapat menumbuhkan motivasi untuk membangun pertanian.

Dengan analisis empat motivasi ini yaitu motivasi lingkungan; motivasi ekonomi; motivasi kesehatan; dan 
motivasi social / kemasyarakatan masyarakat, diharapkan dapat menjadi masukan dan bahan pertimbangan bagi pengambil kebijakan. Berdasarkan latar belakang tersebut, tujuan dari penelitian ini adalah mengidentifikasi karakteristik pertanian perkotaan dan menganalisis pemanfaatan pekarangan untuk pertanian perkotaan sehingga pengembangan pertanian perkotaan dapat tepat sasaran, berkelanjutan dan berkesinambungan.

Penelitian ini dilakukan di Kota Muara Bungo, di mana masyarakat yang menjadi obyek penelitian ini memanfaatkan pekarangan untuk berusahatani sayur dan/ atau buah tergabung dalam kelompok tani yang berada pada kelompok Tani di Dusun
Suka Makmur Kecamatan Bathin II Babeko Kabupaten Bungo, kelompok tani ini bergerak dibidang tanaman pangan.

\section{Metodologi Penelitian}

Penelitian ini menggunakan metode penelitian deskriptif dengan pendekatan kualitatif dan teknik survei menggunakan kuesioner. Motivasi diukur menggunakan skala likert dari item pernyataan (Tabel 1). Setiap pernyataan diberi skor 1 sampai dengan 5 sesuai dengan jawaban yang disediakan yaitu SI = Sangat Ingin, I = Ingin, $\mathrm{N}=$ Netral, $\mathrm{TI}=$ Tidak Ingin, $\mathrm{STI}=$ Sangat Tidak Ingin. Jawaban dihitung, dipersentasekan dan skala interval digunakan untuk mengkategorikan motivasi tinggi, sedang dan rendah.

Tabel 1. Item Pernyataan Pengukuran Motivasi Lingkungan, Motivasi Ekonomi, Motivasi Kesehatan dan Motivasi Sosial/Kemasyarakatan

\begin{tabular}{|c|c|c|c|c|}
\hline No & Lingkungan & Ekonomi & Kesehatan & Sosial/Kemasyarakatan \\
\hline 1 & $\begin{array}{l}\text { Keinginan memberi warna } \\
\text { pada pekarangan dengan } \\
\text { menanam sayuran buah } \\
\text { (terong, tomat, dan cabai) }\end{array}$ & $\begin{array}{l}\text { Keinginan mengurangi } \\
\text { pengeluaran }\end{array}$ & $\begin{array}{lr}\text { Keinginan } & \text { mem } \\
\text { berikan } & \text { makanan } \\
\text { yang } & \\
\text { hiegienis } & \text { bebas } \\
\text { pestisida } & \text { bagi } \\
\text { keluarga } & \end{array}$ & $\begin{array}{l}\text { Keinginan bergabung } \\
\text { dengan kelompok tani }\end{array}$ \\
\hline 2 & $\begin{array}{lr}\text { Keinginan menjadikan } \\
\text { pekarangan terlihat indah } \\
\text { dengan } \\
\text { sayuran/buah }\end{array}$ & $\begin{array}{l}\text { Keinginan mengurangi } \\
\text { biaya transportasi ke } \\
\text { warung/super market } \\
\text { untuk membeli sayuran }\end{array}$ & $\begin{array}{l}\text { Keinginan } \\
\text { memberikan } \\
\text { makanan } \\
\text { bermutu } \\
\text { keluarga }\end{array}$ & $\begin{array}{l}\text { keinginan menjadi tempat } \\
\text { orang-orang bertanya } \\
\text { tentang bertanam buah } \\
\text { dan sayur }\end{array}$ \\
\hline 3 & $\begin{array}{l}\text { Keinginan menjadikan } \\
\text { rumah terasa sejuk dan } \\
\text { nyaman dengan adanya } \\
\text { tanaman sayuran/buah }\end{array}$ & $\begin{array}{l}\text { Keinginan mengurangi } \\
\text { biaya untuk liburan } \\
\text { dengan merawat tanaman }\end{array}$ & $\begin{array}{l}\text { Keinginan } \\
\text { memberikan } \\
\text { makanan yang segar } \\
\text { bagi keluarga }\end{array}$ & $\begin{array}{l}\text { Keinginan berbagi hasil } \\
\text { panen dengan tetangga } \\
\text { atau tamu yang dating }\end{array}$ \\
\hline 4 & $\begin{array}{l}\text { Keinginan menjadikan } \\
\text { udara diluar rumah terasa } \\
\text { lebih segar }\end{array}$ & $\begin{array}{l}\text { Keinginan } \\
\text { memanfaatkan waktu } \\
\text { senggang menjadi lebih } \\
\text { produktif }\end{array}$ & $\begin{array}{l}\text { Keinginan } \\
\text { memperbaiki gizi } \\
\text { kelurarga }\end{array}$ & \begin{tabular}{lrr} 
Keinginan & \multicolumn{2}{c}{ mengikuti } \\
tetangga & yang & juga \\
bertanaman & buah & dan \\
sayuran & &
\end{tabular} \\
\hline 5 & $\begin{array}{l}\text { Keinginan membuat } \\
\text { halaman rumah tidak } \\
\text { terlihat gersang }\end{array}$ & $\begin{array}{l}\text { Keinginan } \\
\text { memanfaatkan sampah } \\
\text { organik untuk membuat } \\
\text { pupuk yang digunakan } \\
\text { untuk tanaman sendiri }\end{array}$ & $\begin{array}{l}\text { Keinginan untuk } \\
\text { dapat menyegarkan } \\
\text { pikiran }\end{array}$ & $\begin{array}{l}\text { Keinginan sebagai } \\
\text { sarana edukasi, mendidik } \\
\text { ang gota keluarga dan } \\
\text { masya rakat untuk cinta } \\
\text { lingkungan }\end{array}$ \\
\hline 6 & $\begin{array}{l}\text { Keinginan memanfaatkan } \\
\text { barang bekas rumah tang } \\
\text { ga untuk digunakan se } \\
\text { bagai wadah tanam (botol } \\
\text { bekas, wadah minyak } \\
\text { goreng, kaleng susu/roti. }\end{array}$ & & $\begin{array}{l}\text { Keinginan } \\
\text { menciptakan } \\
\text { keanekaragaman } \\
\text { makananan keluarga }\end{array}$ & $\begin{array}{l}\text { Keinginan melestarikan } \\
\text { budaya menanam }\end{array}$ \\
\hline
\end{tabular}


Teknik sampling dalam penelitian ini menggunakan metode simple random sampling dan purposive sampling (Sugiyono, 2008). Dikatakan simple random sampling karena pengambilan anggota sampel dari populasi dilakukan secara acak tanpa memperhatikan strata yang ada dalam populasi itu (Sugiyono, 2008). Jadi seluruh populasi memiliki kesempatan yang sama untuk dijadikan sampel, yaitu pada rumah-rumah yang memanfaatkan pekarangan untuk bertanam sayur dan/atau buah. Diperoleh 113 responden, yang terdiri dari 77 responden Adapun penelitian ini dilaksanakan di Dusun Suka Makmur kecamatan bathin II Babeko Kabupaten Bungo.

\section{Hasil dan Pembahasan}

Berdasarkan hasil penyebaran kuesioner terhadap 79 (Tujuh Puluh Sembilan ) pertanian perkotaan dengan karakteristik pertanian perkotaan pada penelitian ini meliputi tingkat usia, tingkat pendidikan, dan jenis kelamin.

a. Usia Responden

Usia penggiat pertanian perkotaan di wilayah studi paling banyak pada usia lebih dari 41 tahun, yaitu sebanyak $41,8 \%$ responden. Sedangkan penggiat paling sedikit di usia 21-30 tahun, yaitu 18\% responden.

b. Tingkat Pendidikan Responden

\begin{abstract}
Penggiat kegiatan
pertanian perkotaan di Dusun

Suka Makmur kecamatan bathin II

Babeko Kabupaten Bungo. paling banyak berlatar belakang pendidikan Sekolah Dasar (SD). Hal ini terlihat dalam hasil penelitian yang menunjukkan bahwa penggiat memiliki tingkat pendidikan pada tingkat SD sebanyak $38 \%$ responden, Paling sedikit pada Perguruan Tinggi sebanyak $3,8 \%$ responden, sementara untuk tingkat SMP yaitu sebanyak 33\% responden, dan SMA sebanyak $25 \%$ responden.

untuk jenis kelamin dari hasil survey diketahui bahwa yang paling banyak penggiat pertanian perkotaan ini adalah perempuan yaitu sebanyak $67 \%$ sementara laki -laki sebanyak 32,3\%, hal ini dapat disebabkan karena perempuan memiliki waktu luang lebih banyak di rumah sehingga bisa memanfaatkan pekarangan untuk kegiatan pertanian.
\end{abstract}

c. Jenis Kelamin

\section{Motivasi Responden}

Penelitian ini melihat dari 4 motif pemanfaatan pekarangan untuk bertanam sayur dan/atau buah yaitu motivasi lingkungan, motivasi ekonomi, motivasi kesehatan dan motivasi social / kemasyarakan. 
Motivasi Lingkungan

Tabel 2. Rekapitulasi Nilai pada Motivasi Lingkungan dalam pemanfaatan pekarangan untuk kegiatan pertanian perkotaan

\begin{tabular}{|c|c|c|c|c|}
\hline No & Pernyataan & $\begin{array}{l}\text { Jumlah } \\
\text { Nilai }\end{array}$ & $\begin{array}{l}\text { Rata-rata } \\
\text { Nilai }\end{array}$ & Kategori Motivasi \\
\hline 1 & $\begin{array}{l}\text { Keinginan memberi warna pada } \\
\text { pekarangan dengan menanam } \\
\text { sayuran buah (terong, tomat, dan } \\
\text { cabai) }\end{array}$ & 340 & 4,43 & Sangat tinggi \\
\hline 2 & $\begin{array}{l}\text { Keinginan menjadikan } \\
\text { pekarangan terlihat indah dengan } \\
\text { bertanam sayuran/buah }\end{array}$ & 341 & 4,26 & Sangat tinggi Baik \\
\hline 3 & $\begin{array}{l}\text { Keinginan menjadikan udara } \\
\text { diluar rumah terasa lebih segar }\end{array}$ & 345 & 4,3 & Sangat tinggi \\
\hline 4 & $\begin{array}{l}\text { Keinginan membuat halaman } \\
\text { rumah tidak terlihat gersang }\end{array}$ & 347 & 4,3 & Sangat tinggi \\
\hline 5 & $\begin{array}{l}\text { Keinginan memanfaatkan barang } \\
\text { bekas rumah tang ga untuk } \\
\text { digunakan se bagai wadah tanam } \\
\text { (botol bekas, wadah minyak } \\
\text { goreng, kaleng susu/roti, dsb) }\end{array}$ & 280 & 3,5 & tinggi \\
\hline $\begin{array}{l}\text { men } \\
\text { Keir } \\
\text { tidal } \\
\text { sebe }\end{array}$ & $\begin{array}{l}\text { Motivasi lingkungan ya } \\
\text { pat pada Tabel } 2 \text { menggambark } \\
\text { va motivasi tertinggi masyara } \\
\text { lanfaatkan pekarangan ada } \\
\text { ginan membuat halaman rum } \\
\text { terlihat gersang dari jumlah } \mathrm{n} \\
\text { sar } 347 \text { dan motivasi terenc } \\
\text { ah Keinginan memanfaatkan bar } \\
\text { s rumah tangga untuk digunal }\end{array}$ & & \multicolumn{2}{|c|}{$\begin{array}{l}\text { sebagai wadah tanam (botol bekas, } \\
\text { wadah minyak goreng, kaleng susu/roti, } \\
\text { dsb). Hal ini disebabkan masyarakat } \\
\text { lebih tertarik untuk menanam langsung } \\
\text { dipekarangan tanpa harus repot } \\
\text { menggunakan media atau wadah, karena } \\
\text { butuh waktu untuk mencari wadah, dan } \\
\text { pekarangan masih cukup luas untuk } \\
\text { ditanam. }\end{array}$} \\
\hline
\end{tabular}




\section{Motivasi Ekonomi}

Tabel 3. Rekapitulasi Nilai pada Motivasi Ekonomi dalam pemanfaatan pekarangan untuk kegiatan pertanian perkotaan

\begin{tabular}{|c|c|c|c|c|}
\hline No & Pernyataan & $\begin{array}{c}\text { Jumlah } \\
\text { Nilai }\end{array}$ & $\begin{array}{c}\text { Rata-rata } \\
\text { Nilai }\end{array}$ & Kategori Motivasi \\
\hline 1 & Keinginan mengurangi pengeluaran & 355 & 4,5 & Sangat tinggi \\
\hline 2 & $\begin{array}{l}\text { Keinginan mengurangi biaya transportasi } \\
\text { ke warung/super market untuk membeli } \\
\text { sayuran }\end{array}$ & 357 & 4,5 & Sangat tinggi Baik \\
\hline 3 & $\begin{array}{l}\text { Keinginan mengurangi biaya untuk } \\
\text { liburan dengan merawat tanaman }\end{array}$ & 335 & 4,2 & Sangat tinggi \\
\hline 4 & $\begin{array}{l}\text { Keinginan memanfaatkan waktu } \\
\text { senggang menjadi lebih produktif }\end{array}$ & 332 & 4,2 & Sangat tinggi \\
\hline 5 & $\begin{array}{l}\text { Keinginan memanfaatkan sampah } \\
\text { organik untuk membuat pupuk yang } \\
\text { digunakan untuk tanaman sendiri }\end{array}$ & 274 & 3,4 & tinggi \\
\hline & $\begin{array}{l}\text { Pada Tabel } 3 \text { dapat dilihat } \\
\text { nyataan pertama motivasi ekonomi } \\
\text { onden yaitu Keinginan mengurangi } \\
\text { geluaran dan Keinginan mengurangi } \\
\text { a transportasi ke warung/super market } \\
\text { lk membeli sayuran memiliki nilai } \\
\text { g hampir sama demikian pula } \\
\text { hyataan ketiga dan ke empat } \\
\text { nginan mengurangi biaya untuk } \\
\text { ran dengan merawat tanaman dan } \\
\text { nginan memanfaatkan waktu }\end{array}$ & $\begin{array}{l}\text { jaul } \\
\text { mer } \\
\text { beg } \\
\text { dan } \\
\text { untı } \\
\text { perr } \\
\text { mer } \\
\text { mer } \\
\text { tanc } \\
\text { tere } \\
\text { sam } \\
\text { sam }\end{array}$ & $\begin{array}{l}\text { berbeda } \\
\text { jukkan bah } \\
\text { mempermas } \\
\text { aya yang ha } \\
\text { memenuhi } \\
\text { taan te } \\
\text { faatkan sa } \\
\text { lat pupuk y } \\
\text { in sendiri ini } \\
\text { artinya } \\
\text { pada tah } \\
\text { untuk dibe }\end{array}$ & $\begin{array}{l}\text { lainya hal ini } \\
\text { masyarakat tidak } \\
\text { hkan tentang waktu } \\
\text { mereka keluarkan } \\
\text { kebutuhan, hanya } \\
\text { a Keinginan } \\
\text { ah organik untuk } \\
\text { g digunakan untuk } \\
\text { yang memiliki nilai } \\
\text { masyarakat belum } \\
\text { untuk mengolah } \\
\text { yakan lebih lanjut. }\end{array}$ \\
\hline
\end{tabular}
senggang menjadi lebih produktif tidak

\section{Motivasi Kesehatan}

Tabel 4. Rekapitulasi Nilai pada Motivasi Kesehatan dalam pemanfaatkan pekarangan untuk kegiatan pertanian perkotaan

\begin{tabular}{|c|c|c|c|c|}
\hline No & Pernyataan & $\begin{array}{l}\text { Jumlah } \\
\text { Nilai }\end{array}$ & $\begin{array}{l}\text { Rata-rata } \\
\text { Nilai }\end{array}$ & $\begin{array}{l}\text { Kategori } \\
\text { Motivasi }\end{array}$ \\
\hline 1 & $\begin{array}{l}\text { Keinginan mem berikan makanan yang } \\
\text { hiegienis bebas pestisida bagi keluarga }\end{array}$ & 374 & 4,7 & $\begin{array}{c}\text { Sangat } \\
\text { tinggi }\end{array}$ \\
\hline 2 & $\begin{array}{l}\text { Keinginan memberikan makanan yang bermutu } \\
\text { bagi keluarga }\end{array}$ & 374 & 4,7 & $\begin{array}{l}\text { Sangat } \\
\text { tinggi Baik }\end{array}$ \\
\hline 3 & $\begin{array}{l}\text { Keinginan memberikan makanan yang segar } \\
\text { bagi keluarga }\end{array}$ & 370 & 4,6 & $\begin{array}{l}\text { Sangat } \\
\text { tinggi }\end{array}$ \\
\hline 4 & Keinginan untuk dapat menyegarkan pikiran & 370 & 4,6 & $\begin{array}{l}\text { Sangat } \\
\text { tinggi }\end{array}$ \\
\hline 5 & Keinginan memperbaiki gizi kelurarga & 356 & 4,5 & $\begin{array}{l}\text { Sangat } \\
\text { tinggi }\end{array}$ \\
\hline 6 & $\begin{array}{l}\text { Keinginan menciptakan keanekaragaman } \\
\text { makananan keluarga }\end{array}$ & 340 & 4,3 & $\begin{array}{l}\text { Sangat } \\
\text { tinggi }\end{array}$ \\
\hline & Motivasi kesehatan yang paling kuat & yaitu & Keinginan & memberik \\
\hline
\end{tabular}


bagi keluarga, Keinginan memberikan makanan yang bermutu bagi keluarga, Keinginan memberikan makanan yang segar bagi keluarga, Keinginan untuk dapat menyegarkan pikiran, Keinginan memperbaiki gizi kelurarga, Pada pernyataan terakhir (pernyataan 6) apakah keinginan menanam sayur dan/atau buah adalah menciptakan keanekaragaman makanan bagi keluarga, untuk masyarakat pinggiran kota pernyataan ini bernilai rendah dari pernyataan lainnya, hal ini dikarenakan anggapan bahwa tanaman yang mereka tanam tidak terlalu beragam. Pada intinya masyarakat lebih mementingkan makanan yang sehat dan bergizi bebas pestisida untuk dikonsumsi dibandingkan keanekaragaman makanan bagi keluarga.

\section{Motivasi Sosial / Kemasyarakatan}

Tabel 5. Rekapitulasi Nilai pada Motivasi Sosial / Kemasyarakatan dalam pemanfaatkan pekarangan untuk kegiatan pertanian perkotaan

\begin{tabular}{|c|c|c|c|c|}
\hline No & Pernyataan & $\begin{array}{c}\text { Jumlah } \\
\text { Nilai }\end{array}$ & $\begin{array}{l}\text { Rata-rata } \\
\text { Nilai }\end{array}$ & $\begin{array}{l}\text { Kategori } \\
\text { Motivasi }\end{array}$ \\
\hline 1 & Keinginan bergabung dengan kelompok tani & 285 & 3,6 & tinggi \\
\hline 2 & $\begin{array}{l}\text { keinginan menjadi tempat orang-orang bertanya } \\
\text { tentang bertanam buah dan sayur }\end{array}$ & 218 & 2,7 & Sedang \\
\hline 3 & $\begin{array}{l}\text { Keinginan berbagi hasil panen dengan tetangga } \\
\text { atau tamu yang datang }\end{array}$ & 295 & 3,7 & tinggi \\
\hline 4 & $\begin{array}{l}\text { Keinginan mengikuti tetangga yang juga } \\
\text { bertanaman buah dan sayuran }\end{array}$ & 206 & 2,6 & Sedang \\
\hline 5 & $\begin{array}{l}\text { Keinginan sebagai sarana edukasi, mendidik ang } \\
\text { gota keluarga dan masya rakat untuk cinta } \\
\text { lingkungan }\end{array}$ & $\lg$ & 2,7 & Sedang \\
\hline 6 & Keinginan melestarikan budaya menanam & 237 & 3 & Sedang \\
\hline \multicolumn{2}{|r|}{$\begin{array}{l}\text { Motivasi sosial/kemasyarakatan } \\
\text { yang paling utama responden adalah } \\
\text { Keinginan berbagi hasil panen dengan } \\
\text { tetangga atau tamu yang datang dan } \\
\text { Keinginan bergabung dengan kelompok } \\
\text { tani,diikuti melestarikan budaya } \\
\text { menanam, lalu secara berturut-turut } \\
\text { keinginan menjadi tempat orang-orang } \\
\text { bertanya tentang bertanam buah dan } \\
\text { sayur, keinginan sebagai sarana edukasi, }\end{array}$} & \multicolumn{3}{|c|}{$\begin{array}{l}\text { masyarakat untuk cinta lingkungan, dan } \\
\text { yang motivasi terakhir adalah keinginan } \\
\text { mengikuti tetangga yang juga bertanam } \\
\text { sayur dan/atau buah. Masyarakat lebih } \\
\text { mengutamakan sifat sosial dalam hal } \\
\text { berbagi dan ini merupakan nilai yang } \\
\text { sudah membudaya dalam masyarakat } \\
\text { yang perlu dilestarikan.Motivasi } \\
\text { memanfaatkan Pekarangan di Kota } \\
\text { Muara Bungo. }\end{array}$} \\
\hline
\end{tabular}


Tabel 6. Rekapitulasi Nilai pada Motivasi masyarakat dalam pemanfaatkan pekarangan untuk kegiatan pertanian perkotaan

\begin{tabular}{clccc}
\hline No & Pernyataan & $\begin{array}{c}\text { Jumlah } \\
\text { Nilai }\end{array}$ & $\begin{array}{c}\text { Rata-rata } \\
\text { Nilai }\end{array}$ & Kategori Motivasi \\
\hline 1 & Motivasi Lingkungan & 1653 & 4,1 & tinggi \\
2 & Motivasi Ekonomi & 1653 & 4,1 & Tinggi \\
3 & Motivasi Kesehatan & 2182 & 4,6 & Sangat tinggi \\
4 & Motivasi & 1452 & 3,06 & Sedang \\
& Sosial/Kemasyarakatan & & & \\
\hline
\end{tabular}

Berdasarkan tabel diatas diketahui bahwa yang menjadi motivasi utama dari keempat motivasi tersebut dalam memanfaatkan pekarangan untuk bertanam sayur dan/atau buah adalah motivasi kesehatan, yaitu Keinginan memberikan makanan yang hiegienis bebas pestisida bagi keluarga dan keinginan memberikan makanan yang bermutu bagi keluarga

Motivasi kedua di pusat kota adalah Motivasi Lingkungan dan Motivasi Ekonomi yaitu Keinginan membuat halaman rumah tidak terlihat gersang dan Keinginan mengurangi pengeluaran dan Keinginan mengurangi biaya transportasi ke warung/super market untuk membeli sayuran.

Urutan terakhir dari motivasi masyarakat ini adalah motivasi sosial/kemasyarakatan responden tapi tetap mempunyai nilai lebih yaitu tingginya Keinginan berbagi hasil panen dengan tetangga atau tamu yang datang, hal ini merupakan nilai budaya dalam motivasi sosial/kemasyarakatan di Dusun Suka Makmur kecamatan bathin II Babeko Kabupaten Bungo.

Secara keseluruhan yang menjadi motivasi masyarakat berturut-turut adalah di mulai dari motivasi kesehatan, kemudian diikuti Motivasi Lingkungan dan Motivasi Ekonomi dan terakhir motivasi sosial/kemasyarakatan, Hasil ini cukup selaras dengan hasil penelitian Specht dkk (2016), yang menunjukkan penerimaan tertinggi masyarakat untuk pertanian di perkotaan komersial haruslah multifungsi dengan tujuan lingkungan dan sosial sedangkan pertanian yang murni berbasis produksi atau berteknologi intensif cenderung ditolak, sehingga untuk menarik partisipasi aktif masyarakat haruslah menekankan pada tujuan-tujuan kesehatan, lingkungan bukan tujuan ekonomi sesuai dengan hasil penelitian bahwa kegagalan dari pertanian perkotaan adalah adanya penekanan berlebihan pada tujuan keuangan (Poulsen, 2017).

\section{Kesimpulan}

Motivasi masyarakat dalam memanfaatkan pekarangan untuk pertanian di Dusun Suka Makmur kecamatan bathin II Babeko Kabupaten Bungo, adalah di mulai dari motivasi kesehatan, kemudian diikuti Motivasi Lingkungan dan Motivasi Ekonomi dan terakhir motivasi sosial/kemasyarakatan. Dalam aplikasi pemanfaatan pekarangan perlu perencanaan dan binaan dari pemerintah setempat yang disesuaikan dengan kondisi dan motivasi masyarakat. Implikasi dari kajian empat motivasi tersebut adalah (1) sebagai sebagai faktor pendukung Kesehatan dari sisi makanan yang sehat (2) pendukung ekonomi untuk mengurangi pengeluaran, (3) manfaat lingkungan berupa optimalisasi pemanfaatan lahan kosong, mengurangi polusi udara, menciptakan keindahan, dan kesejukan. Secara tidak langsung, pertanian perkotan ini tidak hanya sebagai gaya hidup di perkotaan saja, tetapi kegiatan pertanian perkotaan ini memberi manfaat sosial berupa pemanfaatan waktu luang dan gotongroyong antar warga mengimplementasikan pola atau konsep pembangunan berkelanjutan yang disesuaikan dengan motivasi masyarakat itu sendiri. 


\section{DAFTAR PUSTAKA}

Battersby, J. dan M. Marshak. 2013. Growing Communities: Integrating the Social and Economic Benefits of Urban Agriculture in Cape Town. Urban Forum, 24(4): 447-461.

Ciftcioglu, G. C. 2017. Assessment Of The Resilience of Socio-Ecological Production Landscapes and Seascapes: A Case Study From Lefke Region of North Cyprus. Ecological Indicators, 73: 128 138.

Corrigan, M. P. 2011. Growing What You Eat: Developing Community Gardens in Baltimore, Maryland. Applied Geography, 31(4): 12321241.

Cultural Geographies, 15 (1): 95117.

Gusfarina, dan Irham Irham. 2019 Mengukur Tingkat Motivasi Masyarakat Terhadap Pemanfaatan Pekarangan Untuk Pertanian Perkotaan Di Kota Yogyakarta, Jurnal Kawistara (9) : (208-291)

Dubbeling, M. dan de Zeeuw, H. 2011. Urban Agriculture and Climate Change Adaptation: Ensuring Food Security Through Adaptation. Resilient Cities, 441449.

Dunn, A. D. 2010. Siting Green Infrastructure: Legal and Policy Solutions to

Alleviate Urban Poverty and Promote Healthy Communities. Environmental Affairs Law Review, 37(1): 41-67.

Egli, V., M. Oliver, dan E. Tautolo. 2016. The Development of a Model of Community Garden Benefits to Wellbeing. Preventive Medicine Reports, 3: 348 352.
Fikriman, F. (2017). Tranformasi Pertanian dan Pembangunan Pedesaan. JAS (Jurnal Agri Sains), 1(2).

Fikriman, F., Budiman, F. A., \& Afrianto, E. (2020). Faktor Sosial Ekonomi yang Mempengaruhi Pengeluaran Pangan Rumah Tangga Miskin di Kecamatan Bangko Kabupaten Merangin. JAS (Jurnal Agri Sains), 4(2), 149-161.

Gauder, M., H. Hagel. N. Gollmann, J. Stangle, R. Doluschitz, dan W. Claupein. 2017. Motivation and Background of Participants and Providers of Self-Harvest Gardens in Germany. Renewable Agriculture and Food Systems, 19.

Guitart, D., C. Pickering, dan J. Byrne. 2012. Urban Forestry and Urban Greening Past Results and Future Directions in Urban Community Gardens Research. Urban Forestry \& Urban Greening, 11(4): 364-373.

Horst, M., N. McClintock, and L. Hoey. 2017. The Intersection of A Review of the Literature. Journal of the American Planning Association, 83 (3): 277-295.

Hovorka, A. 2008. Transspecies Urban Theory: Chickens in an African City.

Mcclintock, N. 2010. Why Farm The City ? Theorizing Urban Agriculture Through a Lens of Metabolic Rift. Cambridge Journal of Regions, Economy and Society 3(2): 191207.

Poulsen, M. N. 2017. Cultivating Citizenship, Equity, and Social Inclusion Putting Civic Agriculture Into Practice Through Urban Farming. Agriculture and Human Values, 34(1): 135-148. 
Simatele, D. M. and T. Binns. 2008. Motivation Marginalization in African Urban Agriculture: The Case of Lusaka, Zambia. Urban Forum, 19(1): 1-21.

Specht, K., T. Weith, K. Swoboda dan R. Siebert. 2016. Socially Acceptable Trendov, N. M. 2018. Annals of Agrarian Science Comparative Study on The Motivations that Drive Urban Community Gardens in Central Eastern Europe. Annals of Agrarian Sciences, 16(1): 85-89.
Urban Agriculture Businesses. Agronomy for Sustainable Development, 36(1): 1-14.

Sugiyono. 2008. Metode Penelitian Kuantitatif, Kualitatif, dan $R \& D$. Bandung: $\quad \mathrm{CV}$ Alfabeta

Turner, B. 2011. Embodied Connections: Sustainability, Food Systems and Community Gardens. Local Environment :The International Journal of Justice and Sustainability, 16(6): 509-522 